\title{
Phytochemical composition and antioxidant activity of two species related to family Arecaceae
}

\author{
Naglaa I Afifi ${ }^{1}$, Abeer S Moawad ${ }^{1}$, Mona H Hetta2 ${ }^{2}$, Rabab M Mohammed ${ }^{1 *}$ \\ ${ }_{1}$ Pharmacognosy Department, Faculty of Pharmacy, Beni-Suef University, Beni-Suef, Egypt \\ 2 Pharmacognosy Department, Faculty of Pharmacy, Fayoum University, Fayoum, Egypt
}

\begin{abstract}
Several studies have focused on the biological and chemical properties of different species of the family Arecaceae. Isolation and characterization of the phytochemicals of Archontophoenix alexandrae (Wendl. \& Drude) and Dictyosperma album (Bory) H.Wendl \& Drude ex Scheff. leaves (family Arecaceae) and determination of their total phenolics, flavonoids contents and antioxidant activity were investigated in this study. Chromatographic and spectral techniques were used for the phytochemical investigation. Total phenolics content was estimated using Folin-Ciocalteu method, total flavonoids content was determined using $\mathrm{AlCl}_{3}$ assay, while antioxidant activity was estimated using DPPH and reducing power assays. Nine compounds; stigmasterol (1), $\beta$-sitosterol (2), tricin (3), luteolin (4), quercetin (5), $\beta$-sitosterol- $\beta$-D-glucoside (6), ent-epicatechin- $(2 \alpha \rightarrow 7,4 \alpha \rightarrow 8)$ ent-catechin (7), rutin $(\mathbf{8})$ and orientin $(\mathbf{9})$ were isolated and identified. Their structures were established based on spectral techniques (UV, ${ }^{1} \mathrm{H},{ }^{13} \mathrm{C}$ and 2D-NMR). The antioxidant activity of Dictyosperma album leaves is higher than that of Archontophoenix alexandrae leaves. This work enriched the phytochemical data of Archontophoenix alexandrae (Wendl. \& Drude) and Dictyosperma album (Bory) H.Wendl \& drudeex.Scheff and their leaves may be a potential antioxidant drug.
\end{abstract}

\section{Keywords:}

Archontophoenix alexandrae, Dictyosperma album, Antioxidant, Arecaceae, Phenolics

\section{INTRODUCTION}

The role of natural products as remedies has been recognized since ancient times. Demand for medicinal plants is increasing in both developed and developing countries due to growing recognition of natural products as being safer and having a potential of large benefits to society. Egyptian flora, being variable, has become an interesting spot to prospect for new chemical leads ${ }^{1}$. So, in recent decades, many studies have been carried out on different plant species to discover compounds of possible interest for different medicinal applications. Among these studies, several have focused on the biological and phytochemical properties of different species of the family Arecaceae $e^{2-4}$. Arecaceae is among the famous plant families which include genera that introduce phenolicrich species. Previous phytochemical investigations have shown that flavonoids, anthocyanidins, lignans, benze- noids, benzoquinone, monoterpenoids, and nor isoprenoids are constituents of family Arecaceae $e^{3,5-7}$.

Archontophoenix alexandrae is known as Alexander palm, king Alexander palm, king palm and northern bangalow palm. It is endemic to northern Queensland and Australia and occurs in the rainforests of tropical and warm temperate regions ${ }^{8}$. It is often used as an ornamental plant ${ }^{9}$. Dictyosperma album has two common names; princess palm and hurricane palm ${ }^{10}$. It is native to Reunion and Mauritius. The root decoction of Dictyosperma album is used as diuretic ${ }^{11-12}$.

It was reported that Archontophoenix alexandrae (Wendl. \& Drude) and Dictyosperma album (Bory) H.Wendl. \& Drude ex Scheff.; family Arecaceae; contain glycoflavones; being with few reports on their chemical constituents ${ }^{13}$; motivated us to investigate their phytochemical constituents and their antioxidant activity.

\section{*Corresponding author:}

*Rabab M Mohammed rababmohammed@pharm.bsu.edu.eg 


\section{EXPERIMENTAL}

\subsection{General experimental procedures}

All NMR spectra were obtained on Bruker Avance III $400 \mathrm{MHz}$ with BBFO Smart Probe and Bruker $400 \mathrm{MHz}$ AEON Nitrogen-Free Magnet (Bruker AG, Switzerland) operating at $400 \mathrm{MHz}$ for proton and $100 \mathrm{MHz}$ for carbon using the residual protons in deuterated solvent as an internal standard. 1D and 2DNMR spectra (HSQC and HMBC) were obtained using standard Bruker pulse programs. Flash Chromatography was conducted by puriFlash ${ }^{\circledR} 4125$ for flash chromategraphy (interchem, France) at Nawah Center, Cairo, Egypt. Column; C18 HP-120.0 g (20 bar), fractions were collected based on photodiode array (PDA) detection.

Column chromatography was performed using silica gel $60(63-200 \mu \mathrm{m})$, polyamide- $6(50-160 \mu \mathrm{m})$ and Sephadex LH-20 (Sigma-Aldrich, Germany). Pre-coated silica gel 60 TLC plates were purchased from Merck (Darmstadt, Germany). Visualization of the TLC plates was achieved with a UV lamp ( $\lambda_{\max } 254$ and $365 \mathrm{~nm}$ ) and $p$-anisaldehyde's reagent/sulphoric acid spray reagent (methanol-formic acid-p-anisaldehyde-sulfuric acid, $85: 10: 0.5: 5)^{14}$.

\subsection{Plant material}

Archontophoenix alexandrae and Dictyosperma album leaves were collected in April 2015 from ElZohorya Garden, Cairo; and El-Orman Public Garden, Giza, respectively. The plants were kindly identified by Dr. Mohamed Gibali, Senior Botanist, Agriculture Research Center, Ministry of Agriculture, Dokki, Giza. Voucher specimens (BUPD-64 and BUPD-65, respecttively) was deposited in Pharmacognosy Department, Faculty of Pharmacy, Beni-Suef University, Beni-Suef, Egypt.

\subsection{Preparation of extracts}

The extraction of the air-dried powdered leaves of Archontophoenix alexandrae and Dictyosperma album ( $1 \mathrm{~g}$, each) was carried out at room temperature separately using $50 \mathrm{ml}$ methanol $(80 \%)$ for $2 \mathrm{~h}$ on an orbital shaker adjusted at $200 \mathrm{rpm}$. The supernatant produced from mixture centrifugation for 20 min was transferred to a $100 \mathrm{ml}$ volumetric flask. The procedure was repeated, and respective supernatant was pooled. The final volume was adjusted to $100 \mathrm{ml}$ and was used for determination of total phenolics content, total flavonoids content and antioxidant activity ${ }^{15}$.

The air-dried powdered leaves of Archontophoenix alexandrae and Dictyosperma album (3.8 and $3.75 \mathrm{~kg}$, respectively) were separately extracted with $80 \%$ ethanol by percolation and the solvent was evaporated under reduced pressure to afford crude extracts (CE) (486 and $615 \mathrm{~g}$, respectively). Four hundred grams of each extract was suspended in distilled water and partitioned with solvents of different polarities ( $n$-hexane, dichloromethane, ethyl acetate, and $n$-butanol) to afford $(75,30$, 14 and $75 \mathrm{~g}$, respectively for Archontophoenix alexandrae) and (16, 20, 26 and $70 \mathrm{~g}$, respectively for Dictyosperma album). These fractions were used for studying their phytochemistry.

\subsection{Determination of total phenolics content}

The total phenolics content was evaluated spectrophotometrically using Folin-Ciocalteu reagent. The methanol extract ( $300 \mu \mathrm{L}$ ) was added to $2.25 \mathrm{ml}$ of Folin-Ciocalteu reagent and wait for $5 \mathrm{~min}$ at room temperature then add to the mixture $2.25 \mathrm{ml}$ of sodium carbonate $(60 \mathrm{~g} / \mathrm{L})$ solution and stand at room temperature for $90 \mathrm{~min}$ then measure the absorbance at $725 \mathrm{~nm}$. The standard curve was prepared using gallic acid as standard. The final results were expressed as $\mathrm{mg}$ gallic acid equivalents in $1 \mathrm{~g}$ of dried sample (mg GAE/g) for total phenolics ${ }^{15}$.

\subsection{Determination of total flavonoids content}

The total flavonoids content was evaluated spectrophotometrically using $\mathrm{AlCl}_{3}$. Methanol extract $(0.5 \mathrm{ml})$ was added to $2.25 \mathrm{ml}$ of distilled water then 0.15 $\mathrm{ml}$ of $5 \% \mathrm{NaNO}_{2}$ solution was added to the mixture. Wait for $6 \mathrm{~min}$. then add to the mixture $0.3 \mathrm{ml}$ of $10 \%$ $\mathrm{AlCl}_{3} .6 \mathrm{H}_{2} \mathrm{O}$ solution. Stand for another 5 minutes then add $1.0 \mathrm{ml}$ of $1 \mathrm{M} \mathrm{NaOH}$. Mix the mixture well using vortex, the absorbance was immediately measured spectrophotometrically at $510 \mathrm{~nm}$. The standard curve was prepared using rutin. The final results were expressed as $\mathrm{mg}$ rutin equivalents in $1 \mathrm{~g}$ of dried sample ( $\mathrm{mg} \mathrm{RE} / \mathrm{g}$ ) for total flavonoids ${ }^{15}$.

\subsection{Isolation of constituents of Archontophoenix alexandrae leaves}

The $n$-hexane fraction (16 g) was saponified by heating under reflux with $50 \mathrm{ml} 10 \%$ alcoholic $\mathrm{KOH}$ and $20 \mathrm{ml}$ benzene for $24 \mathrm{~h}$ to ensure complete saponification. Benzene was evaporated, and the solution was suspended in $80 \mathrm{ml}$ distilled $\mathrm{H}_{2} \mathrm{O}$ followed by extraction with diethyl ether $(10 \times 100 \mathrm{ml})$ till exhaustion. The combined ethereal extracts were washed several times with distilled $\mathrm{H}_{2} \mathrm{O}$ till free from alkalinity then dried over anhydrous sodium sulphate, followed by evaporation to dryness. The solvent-free residue obtained represent the unsaponifiable matters (USM) ${ }^{16}$. USM of the leaves $(2.6 \mathrm{~g})$ was chromatographed over silica gel column (75 $\mathrm{g}, 29 \times 2.5 \mathrm{~cm}$ ); gradient elution was carried out using $n$ hexane-ethyl acetate mixture in 5\% increments. Frac- 
tions ( $25 \mathrm{ml}$, each) were collected and monitored by TLC using solvent system $n$-hexane/ethyl acetate $(9: 1 \mathrm{v} / \mathrm{v})$. Chromatograms were examined after spraying with $p$ anisaldehyde/sulfuric acid and heating at $110^{\circ} \mathrm{C}$. Fractions eluted with hexane/ethyl acetate (9:1) showed one spot which gave violet colour with $p$-anisaldehyde/ sulfuric acid spray reagent. The fractions were collected and evaporated under reduced pressure to yield white ppt (mixture of compounds $1 \& 2 ; 20 \mathrm{mg}$ ).

Two grams of the dichloromethane extract (ALD) was chromatographed on silica column (60 g, $1.8 \times 38 \mathrm{~cm}$ ) using mixtures of dichloromethane-methanol in $5 \%$ increments to obtain three sub-fractions (ALD-I \& ALD-II \& ALD-III). ALD-I (500 mg, eluted with $10 \%$ methanol in dichloromethane) was rechromatographed on silica column $(50 \mathrm{~g}, 1.8 \times 45 \mathrm{~cm})$ in the same way followed by filtration through Sephadex LH-20 column using methanol as eluent to obtain compound $\mathbf{3}(10 \mathrm{mg})$. ALD-II (700 mg, eluted with $10-15 \%$ methanol in dichloromethane) was chromatographed several times on Sephadex LH-20 column using methanol as eluent to obtain compound $4(30 \mathrm{mg}) \& 5(20 \mathrm{mg})$. ALD-III (50 $\mathrm{mg}$, eluted with $15-20 \%$ methanol in dichloromethane) was washed several times using a mixture of methanol and dichloromethane (1:1) to obtain compound $6(15 \mathrm{mg})$.

TLC investigation of the ethyl acetate and $n$ butanol fractions with different solvent systems showed similar spots so that both fractions were combined (ALP) and a part of the extract $(17 \mathrm{~g})$ was chromate-graphed on silica column $(170 \mathrm{~g}, 2.7 \times 59.5 \mathrm{~cm})$ using mixtures of dichloromethane-methanol in $10 \%$ increments to obtain two sub-fractions. Similar fractions were collected to afford two major fractions (ALP-I \& ALP-II). Fraction ALP-I (200 mg, eluted with 40\% methanol in dichloromethane) was purified on Sephadex LH-20 column using methanol as eluent to obtain compound 7 (10 $\mathrm{mg})$. Fraction ALP-II ( $2.5 \mathrm{~g}$, eluted with 50\% methanol in dichloromethane) was rechromatographed on Sephadex LH-20 column using methanol as eluent to obtain compound 8 (10 mg).

\subsection{Isolation of the constituents of Dictyosperma album leaves}

The $n$-hexane fractions (16 g) was saponified by the same method as in Archontophoenix alexandrae leaves. The USM was subjected to TLC against that of Archontophoenix alexandrae. The chromatograms were developed using different solvent systems and spots were located by spraying with $p$-anisaldehyde $/ \mathrm{H}_{2} \mathrm{SO}_{4}$. The chromatograms revealed the presence of the same spots (compound $1 \& 2$ ).

The dichloromethane extract (DLD; $20 \mathrm{~g}$ ), was sub fractionated using vacuum liquid chromatographic column $(200 \mathrm{~g}, 30 \times 5 \mathrm{~cm})$. Elution was started with dichloromethane in $10 \%$ increments of methanol. Frac- tions (200 ml, each) were collected and monitored by TLC. Similar fractions were pooled together to yield main two subfractions (DLD-I and DLD-II). DLD-I (750 $\mathrm{mg}$, eluted with $10 \%$ methanol in dichloromethane) was rechromatographed on silica column $(1.8 \times 45 \mathrm{~cm})$ using mixtures of dichloromethane/methanol as eluent in 5\% increments. The fraction eluted with $10-15 \%$ methanol in dichloromethane was purified several times on Sephadex LH-20 column using methanol as eluent to obtain compound $3(12 \mathrm{mg})$. DLD-II (300 mg, eluted with $15-20 \%$ methanol in dichloromethane) was recrystalized using methanol and dichloromethane to obtain compound $\mathbf{6}(15 \mathrm{mg})$.

TLC investigation of the ethyl acetate and $n$ butanol fractions with different solvent systems showed similar spots so that both fractions were combined (DLP) and fractionated on polyamide using water/ methanol gradient to obtain two main sub-fractions; DLP-I and DLP-II. DLP-I (1 g, eluted with 20-30\% methanol in water) was chromatographed on silica gel column $(40 \times 1.8 \mathrm{~cm})$ using mixtures of dichloromethane/methanol in $10 \%$ increments to obtain main subfractions which was purified on Sephadex LH-20 column using methanol as eluent to obtain compound $\mathbf{8}$ $(10 \mathrm{mg})$. DLP-II $(1.5 \mathrm{~g}$, eluted with $60 \%$ methanol in water) was chromatographed on Puriflash ${ }^{\circledR}$ column using water (A)-methanol (B) each containing $0.03 \%$ formic acid in a gradient mode: A/B 65/35; 1 CV-65/3550/50; $3 \mathrm{CV}, 50 / 50-35 / 65 ; 5 \mathrm{CV}, 35 / 65-20 / 80 ; 7 \mathrm{CV}$, 20/80-0/100; $8 \mathrm{CV}$. The fraction eluted with $1.99 \mathrm{CV}$ was purified on Sephadex LH-20 column using methanol as eluent to obtain compound 9 ( $30 \mathrm{mg})$.

\subsection{In-vitro antioxidant activity.}

The antioxidant properties were evaluated by free radical scavenging assay (DPPH assay) and iron reducing power $(\mathrm{RP})$.

\subsubsection{DPPH scavenging assay ${ }^{15}$}

In-vitro antioxidant activity was evaluated spectrophotometrically for leaves of Archontophoenix alexandrae and Dictyosperma album using DPPH assay. Three hundred $\mu 1$ of $80 \%$ methanol extracts were added to $3.0 \mathrm{ml}$ of $500 \mu \mathrm{M}$ DPPH in absolute ethanol. Shake the mixture vigorously and wait for $30 \mathrm{~min}$ in the dark at room temperature. The absorbance was measured spectrophotometrically at $517 \mathrm{~nm}$. Ascorbic acid was used as a positive control. The following equation was used to calculate the free radical scavenging activity.

Scavenging effect $(\%)=[1-($ absorbance of sample/absorbance of control)] x 100

The results were expressed as $\mu \mathrm{g}$ ascorbic acid equivalent antioxidant capacity in $1 \mathrm{~g}$ of sample $(\mu \mathrm{g}$ $\mathrm{AEAC} / \mathrm{g})$. 


\subsubsection{Iron reducing power}

The reducing power was evaluated according to Cobaleda-Velasco et al. $2017^{17}$. One hundred $\mu \mathrm{L}$ of each extract were mixed with $250 \mu \mathrm{L}$ of $0.2 \mathrm{M}$ phosphate buffer (pH 6.6) and $250 \mu \mathrm{L}$ of $30 \mathrm{mM} \mathrm{K}_{3} \mathrm{Fe}(\mathrm{CN})_{6}$ and incubated in dark for $20 \mathrm{~min}$ at $50^{\circ} \mathrm{C}$. Then $250 \mu \mathrm{L}$ of $0.6 \mathrm{M}$ trichloroacetic acid were added. Samples were centrifuged (10 min, $2000 \mathrm{rpm})$ and $200 \mu \mathrm{L}$ of supernatant were removed, which were then mixed with 200 $\mu \mathrm{L}$ of double-distilled water and $40 \mu \mathrm{L}$ of $0.1 \% \mathrm{FeCl}_{3}$ $(\mathrm{w} / \mathrm{v})$. Samples were incubated for $10 \mathrm{~min}$. The formation of ferrous ions $\left(\mathrm{Fe}^{2+}\right)$ was registered by the absorbance at $700 \mathrm{~nm}$. The highest absorbance values, the greatest capacity of reducing ferric $\left(\mathrm{Fe}^{3+}\right)$ to ferrous $\left(\mathrm{Fe}^{2+}\right)$ ions. Ascorbic acid $(0.1 \mathrm{mg} / \mathrm{ml})$ was analysed as reference.

\section{Statistical analysis}

All experiments were carried out three times and the results were represented as mean \pm standard errors. Microsoft Excel Windows 2010 was used to calculate the linear regression analysis.

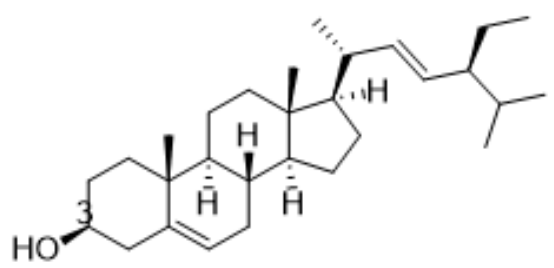

1<smiles>[R]c1cc(-c2oc3c([R])c(O)cc(O)c3c(=O)c2[R])cc([R])c1O</smiles>

$\begin{array}{ccccc}\text { Compound } & \mathrm{R}_{1} & \mathrm{R}_{2} & \mathrm{R}_{3} & \mathrm{R}_{4} \\ \mathbf{3} & \mathrm{H} & \mathrm{H} & \mathrm{OCH}_{3} & \mathrm{OCH}_{3} \\ \mathbf{4} & \mathrm{H} & \mathrm{H} & \mathrm{OH} & \mathrm{H} \\ \mathbf{5} & \mathrm{OH} & \mathrm{H} & \mathrm{OH} & \mathrm{H} \\ \mathbf{8} & \text { O-rutinoside } & \mathrm{H} & \mathrm{OH} & \mathrm{H} \\ \mathbf{9} & \mathrm{H} & \text { C-glu } & \mathrm{OH} & \mathrm{H}\end{array}$

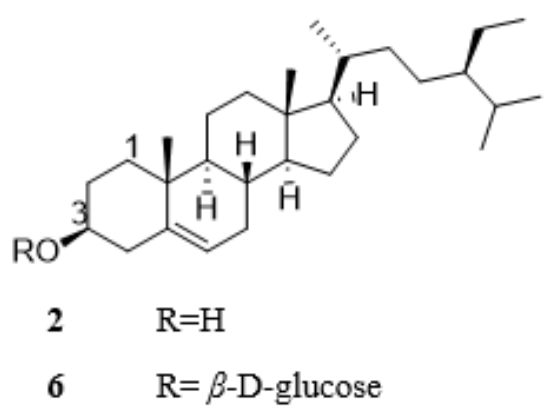

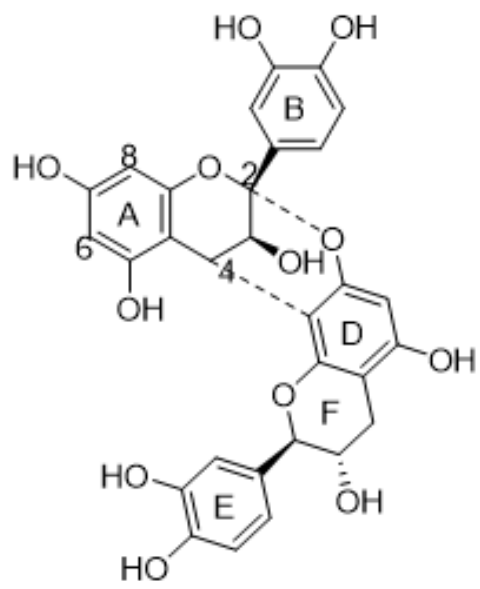

7

Figure 1. Chemical structures of isolated compounds (1-9) from Archintophoenix alexandae and Dictyosperma album leaves.

\section{RESULTS AND DISCUSSION}

Plant and plant products are source of medicine since long. Natural antioxidants are responsible for inhibiting the consequences of oxidative stress. Many medicinal plants are potential sources of antioxidant compounds. Recent studies have shown that many phenolic constituents derived from different species of family Arecaceae are more effective as antioxidant drugs. Phytochemical investigation of Archontophoenix alexandrae and Dictyosperma album leaves resulted in flavonoids are the major polyphenol class present in the tested extracts. As phytochemical investigation of Archontophoenix alexandrae led to the isolation and characterization of eight compounds (Figure 1); stigmasterol and $\beta$-sitosterol mixture (1 \& 2), tricin (3), luteolin (4), quercetin (5), $\beta$-sitosterol- $\beta$-D-glucoside (6), entepicatechin- $(2 \alpha \rightarrow 7,4 \alpha \rightarrow 8)$-ent-catechin (7) and rutin (8). 
While phytochemical investigation of Dictyosperma album led to the isolation and characterization of six compounds (Figure 1); stigmasterol and $\beta$-sitosterol mixture $(\mathbf{1} \& \mathbf{2})$, tricin $(3), \beta$-sitosterol- $\beta$-D-glucoside $(6)$, rutin $(\mathbf{8})$ and orientin (9). The NMR data of the isolated compounds were compared with published one. This is the first report for the isolation of these compounds from these species.

\section{Spectral data of the isolated compounds}

\section{$\beta$-sitosterol (1)}

${ }^{13} \mathrm{C}$ NMR (100 MHz, $\left.\mathrm{CDCl}_{3}\right): 37.2(\mathrm{C}-1), 31.6$ (C-2), 71.8 (C-3), 42.2 (C-4), 140.7 (C-5), 121.7 (C-6), 31.9 (C-7), 31.9 (C-8), 50.1 (C-9), 36.5 (C-10), 21.06 (C11), 39.7 (C-12), 42.19 (C-13), 56.8 (C-14), 24.4 (C-15), 28.9 (C-16), 55.9 (C-17), 12.04 (C-18), 19.4 (C-19), 36.1 (C-20), 21.09 (C-21), 33.9 (C-22), 26 (C-23), 45.8 (C-24), 31.9 (C-25), 21.2 (C-26), 18.9 (C-27), 25.4 (C-28) and $12.3(\mathrm{C}-29)$.

\section{Stigmasterol (2)}

${ }^{13} \mathrm{C}$ NMR (100 MHz, $\left.\mathrm{CDCl}_{3}\right): 37.2(\mathrm{C}-1), 31.6$ (C-2), 71.8 (C-3), 42.2 (C-4), 140.7 (C-5), 121.7 (C-6), 31.9 (C-7), 31.9 (C-8), 50.1 (C-9), 36.5 (C-10), 21.06 (C11), 39.7 (C-12), 42.19 (C-13), 56.8 (C-14), 24.4 (C-15), 28.9 (C-16), 55.9 (C-17), 12.04 (C-18), 19.4 (C-19), 40.5 (C-20), 18.8 (C-21), 138.3 (C-22), 129.2 (C-23), 51.2 (C24), 29.1 (C-25), 19.02 (C-26), 19.8 (C-27), 23 (C-28) and 11.8 (C-29).

\section{Tricin (3)}

${ }^{1} \mathrm{H}$ NMR (400 MHz, $\left.\mathrm{CDCl}_{3}\right): 6.63(1 \mathrm{H}, \mathrm{s}, \mathrm{H}-3)$, 6.17 (1H, s, H-6) 6.44 (1H, s, H-8), 7.21 (2H, s, H-2'\&6') and $3.92\left(6 \mathrm{H}, \mathrm{s}, \mathrm{OCH}_{3}\right)$.

\section{Luteolin (4)}

${ }^{1} \mathrm{H}$ NMR (400 MHz, $\left.\mathrm{CDCl}_{3}\right): 6.53(1 \mathrm{H}, \mathrm{s}, \mathrm{H}-3)$, $6.20(1 \mathrm{H}, \mathrm{d}, J=2.4 \mathrm{~Hz}, \mathrm{H}-6), 6.43(1 \mathrm{H}, \mathrm{d}, J=2.4 \mathrm{~Hz}, \mathrm{H}-8)$, $7.36\left(1 \mathrm{H}\right.$, overlapped, H-2'), $6.89\left(1 \mathrm{H}, \mathrm{d}, J=9.2 \mathrm{~Hz}, \mathrm{H}-5^{\prime}\right)$, $7.38\left(1 \mathrm{H}\right.$, overlapped, $\left.\mathrm{H}-6^{\prime}\right)$.

\section{Quercetin (5)}

${ }^{1} \mathrm{H}$ NMR $\left(400 \mathrm{MHz}, \mathrm{CDCl}_{3}\right): 6.19(1 \mathrm{H}, \mathrm{d}, J=2$ $\mathrm{Hz}, \mathrm{H}-6), 6.41(1 \mathrm{H}, \mathrm{d}, J=2 \mathrm{~Hz}, \mathrm{H}-8), 7.74(1 \mathrm{H}, \mathrm{d}, J=2.4$ Hz, H-2) $) 6.90\left(1 \mathrm{H}, \mathrm{d}, J=8.4, \mathrm{H}-5^{\prime}\right), 7.64(1 \mathrm{H}, \mathrm{dd}, J=2,8.4$ $\left.\mathrm{Hz}, \mathrm{H}-6^{\prime}\right)$.

\section{$\beta$-sitosterol-3- $O-\beta$-D-glucopyranoside (6)}

${ }^{13} \mathrm{C}$ NMR (100 MHz, Pyridine-d $\left.\mathrm{d}_{5}\right): 37.8(\mathrm{C}-1)$, 30.6 (C-2), 78.4 (C-3), 39.7 (C-4), 141.2 (C-5), 122.2 (C6), 32.5 (C-7), 32.4 (C-8), 50.01 (C-9), 37.2 (C-10), 21.6 (C-11), 40.3 (C-12), 42.8 (C-13), 57.1 (C-14), 24.8 (C-15), 28.9(C-16), 56.6 (C-17), 12.3 (C-18), 19.5 (C-19), 36.7 (C20), 19.3 (C-21), 34.5 (C-22), 26.7 (C-23), 46.4 (C-24), 29.8 (C-25), 20.3 (C-26), 19.7 (C-27), 23.7 (C-28), 12.5(C-
29), $102.9\left(\mathrm{C}-1^{\prime}\right), 75.7\left(\mathrm{C}-2^{\prime}\right), 78.9$ (C-3'), 72.0 (C-4), 78.8 (C-5), $63.2\left(\mathrm{C}-6^{\prime}\right)$.

Entepicatechin-( $2 \alpha \rightarrow 7,4 \alpha \rightarrow 8)$-ent-catechin (7) ${ }^{1} \mathrm{H}$ NMR $\left(400 \mathrm{MHz}, \mathrm{CD}_{3} \mathrm{OD}\right): 4.13(1 \mathrm{H}, \mathrm{d}$, $J=3.2 \mathrm{~Hz}, \mathrm{H}-3), 4.24(1 \mathrm{H}, \mathrm{d}, J=2.8 \mathrm{~Hz}, \mathrm{H}-4), 5.92(1 \mathrm{H}, \mathrm{d}$, $J=1.6 \mathrm{~Hz}, \mathrm{H}-6), 6.06(1 \mathrm{H}, \mathrm{d}, J=1.6 \mathrm{~Hz}, \mathrm{H}-8), 7.14(1 \mathrm{H}, \mathrm{br}$ $\mathrm{s}, \mathrm{H}-10), 6.83(1 \mathrm{H}$, overlapped, H-13), $7.02(1 \mathrm{H}, \mathrm{br} \mathrm{d}, \mathrm{H}-$ 14), 4.73 (d, $\left.J=8 \mathrm{~Hz}, \mathrm{H}-2^{\prime}\right), 4.06\left(1 \mathrm{H}, \mathrm{m}, \mathrm{H}-3^{\prime}\right), 2.55(1 \mathrm{H}$, dd, $\left.J=8.4,16.4 \mathrm{~Hz}, \mathrm{H}-4^{\prime}\right), 2.95(1 \mathrm{H}, \mathrm{dd}, J=5.6,16.8 \mathrm{~Hz}, \mathrm{H}-$ 4'), $6.08\left(1 \mathrm{H}, \mathrm{s}, \mathrm{H}-6^{\prime}\right), 6.96\left(1 \mathrm{H}, \mathrm{br} \mathrm{s}, \mathrm{H}-10^{\prime}\right), 6.81(1 \mathrm{H}, \mathrm{d}$, $\left.J=8 \mathrm{~Hz}, \mathrm{H}-13^{\prime}\right)$ and $6.84\left(1 \mathrm{H}\right.$, overlapped, $\left.\mathrm{H}-14^{\prime}\right) .{ }^{13} \mathrm{C}$ NMR (100 MHz, CD $\left.{ }_{3} \mathrm{OD}\right): \delta_{\mathrm{C}} 100.4$ (C-2), 67.6 (C-3), 29.2 (C-4), 104.5 (C-4a), 156.6 (C-5), 98.1 (C-6), 158.1 (C-7), 96.5 (C-8), 154.1 (C-8a), 132.2 (C-9), 115.6 (C-10), 146.8 (C-11), 145.6 (C-12), 116.3 (C-13), 119.8 (C-14), 83.8 (C-2'), 68.3 (C-3'), 28.8 (C-4'), 102.8 (C-4a'), 156.1 (C-5'), 96.6 (C-6'), 152.2 (C-7'), 106.5 (C-8'), 150.8 (C8a'), 130.9 (C-9'), $115.4\left(\mathrm{C}-10^{\prime}\right), 146.7$ (C-11'), 146.4 (C$\left.12^{\prime}\right), 115.7\left(\mathrm{C}-13^{\prime}\right)$, and $120.3\left(\mathrm{C}-14^{\prime}\right)$.

\section{Rutin (8)}

${ }^{1} \mathrm{H}$ NMR (400 MHz, $\left.\mathrm{CD}_{3} \mathrm{OD}\right): 6.20(1 \mathrm{H}, \mathrm{d}, J=2$ $\mathrm{Hz}, \mathrm{H}-6), 6.39(1 \mathrm{H}, \mathrm{d}, J=2.1 \mathrm{~Hz}, \mathrm{H}-8), 7.66(1 \mathrm{H}, \mathrm{d}, J=2.2$ $\left.\mathrm{Hz}, \mathrm{H}-2^{\prime}\right), 6.87\left(1 \mathrm{H}, \mathrm{d}, J=8.4 \mathrm{~Hz}, \mathrm{H}-5^{\prime}\right), 7.62(1 \mathrm{H}, \mathrm{dd}, J=2$, $\left.8.4 \mathrm{~Hz}, \mathrm{H}-6^{\prime}\right), 5.1\left(1 \mathrm{H}, \mathrm{d}, J=7.7 \mathrm{~Hz}, \mathrm{H}-1^{\prime \prime}\right), 3.3-3.8$ (sugar protons), $4.51\left(1 \mathrm{H}, \mathrm{br} \mathrm{s}, \mathrm{H}-1^{\prime \prime \prime}\right)$ and $1.13(1 \mathrm{H}, \mathrm{d}, J=5.6 \mathrm{~Hz}$, H-6"'). ${ }^{13} \mathrm{C}$ NMR (100 MHz, CD 3 OD): 159.3 (C-2), 135.6 (C-3), 179.4 (C-4), 163 (C-5), 100 (C-6), 166 (C-7), 94.9 (C-8), 158.6 (C-9), 105.6 (C-10), 123.1 (C-1), 117.7 (C2), 145.9 (C-3), 149.8 (C-4), 116.1 (C-5'), 123.5 (C-6), 104.7 (C-1"), 75.7 (C-2"), 78.2 (C-3"), 77.2 (C-4"), 71.4 (C-5'), $68.6\left(\mathrm{C}-6^{\prime \prime}\right), 102.4\left(\mathrm{C}-1^{\prime \prime \prime}\right), 72.1\left(\mathrm{C}-2^{\prime \prime \prime}\right), 72.2$ (C3"'), $73.9\left(\mathrm{C}-4^{\prime \prime \prime}\right), 69.6\left(\mathrm{C}-5^{\prime \prime}\right)$ and $17.8\left(\mathrm{C}-6^{\prime \prime \prime}\right)$.

\section{Orientin (9)}

${ }^{1} \mathrm{H}$ NMR (400 MHz, CD $\left.{ }_{3} \mathrm{OD}\right): 6.27(1 \mathrm{H}, \mathrm{s}, \mathrm{H}-$ 3), $6.64(1 \mathrm{H}, \mathrm{s}, \mathrm{H}-8), 7.48$ (1H, overlapped, H-2'), 6.86 $\left(1 \mathrm{H}, \mathrm{d}, J=8.4 \mathrm{~Hz}, \mathrm{H}-5^{\prime}\right), 7.52(1 \mathrm{H}$, overlapped, H-6'), 4.69 $\left(1 \mathrm{H}, \mathrm{d}, \mathrm{J}=5.6 \mathrm{~Hz}, \mathrm{H}-\mathrm{1}^{\prime \prime}\right), 3.3-3.8$ (sugar protons) ${ }^{13} \mathrm{C}$ NMR (100 MHz, CD $\left.{ }_{3} \mathrm{OD}\right): 159.3$ (C-2), 102.3 (C-3), 182 (C-4), 160.3 (C-5), 98.1 (C-6), 162.6 (C-7), 104.5 (C-8), 156 (C9), 104 (C-10), 121.9 (C-1'), 114 (C-2), 145.8 (C-3), 149.6 (C-4), 115.6 (C-5), 119.3 (C-6'), 73.3 (C-1"), 70.9 $\left(\mathrm{C}-2^{\prime \prime}\right), 78.7\left(\mathrm{C}-3^{\prime \prime}\right), 70.6\left(\mathrm{C}-4^{\prime \prime}\right), 82\left(\mathrm{C}-5^{\prime \prime}\right)$ and $61.6(\mathrm{C}-$ 6").

Compound 1 \& 2: Stigmasterol and $\beta$ sitosterol mixture: white powder, soluble in dichloromethane, attained violet color after spraying with $p$ anisaldehyde followed by heating at $110^{\circ} \mathrm{C}$ using precoated silica gel TLC plates. It gives $R_{f}$ value of 0.53 with $n$-hexane/ethyl acetate $(8: 2 \mathrm{v} / \mathrm{v})$. The DEPT-Q spectrum shows four olefinic carbons $\left(\delta_{C} 121.7,129.2\right.$, $138.3,140.7)$; An oxymethine carbon $\left(\delta_{\mathrm{C}} 71.8\right)$; seven methine carbons $\left(\delta_{\mathrm{C}} 31.9(2 \mathrm{x}), 40.4,50.1,51.2,56.07\right.$, $56.7)$; two quaternary carbons $\left(\delta_{\mathrm{C}} 36.5,42.3\right)$; nine 
methylene carbons $\left(\delta_{\mathrm{C}} 21.09,24.3,25.4,28.9,31.6,31.9\right.$, $37.2,39.7,42.3)$; and six methyl carbons $\left(\delta_{\mathrm{C}} 12.05\right.$, $12.24,18.78,19.4,19.81,21.2)$. These are characteristic resonances of a sterol with two olefinic bonds and an alcohol group. The ${ }^{1} \mathrm{H}-\mathrm{NMR}$ spectrum indicated that the three olefinic methine signals at $\delta_{\mathrm{H}} 5.03(\mathrm{dd}, J=8,14.8$ $\mathrm{Hz}), 5.17(\mathrm{dd}, J=8,14.8 \mathrm{~Hz})$, and $5.37(\mathrm{~d}, J=4.4 \mathrm{~Hz}$ are not equally integrated as three protons which was inconsistent with a single compound, a mixture of stigmasterol and $\beta$-sitosterol was suggested. The signal at $5.37(\mathrm{~d}$, $J=4.4 \mathrm{~Hz}$ ) is a common signal in both compounds (H6) integrated as one proton while the signal at $\delta_{\mathrm{H}} 5.03(\mathrm{dd}$, $J=8,14.8 \mathrm{~Hz}$ ) which corresponds to one proton of stigmasterol only was integrated as 0.35 . So, the share of stigmasterol in signal at 5.37 is also 0.35 and the share of $\beta$-sitosterol is 0.65 . So, the ratio of stigmasterol to $\beta$-sitosterol was about 1:2. $\beta$-sitosterol and stigmasterol are always in a mixture form if present in the same plant ${ }^{18}$.

Compound 3: Tricin: yellow powder, soluble in methanol, attained a purple color under long-wave UV light which turned yellow after spraying with $\mathrm{AlCl}_{3}$ and after spraying with $p$-anisaldehyde followed by heating at $110^{\circ} \mathrm{C}$ using precoated silica gel TLC plates indicating its flavone nature. It gives $\mathrm{R}_{\mathrm{f}}$ value of 0.58 with dichloromethane/methanol (9.5:0.5 v/v). ${ }^{1} \mathrm{H}-\mathrm{NMR}$ spectrum showed three signals appeared at $\delta_{\mathrm{H}} 6.63(\mathrm{~s}), 6.17(\mathrm{~s})$ and 6.44 (s) which were assignable to H-3, H-6 and H8 , respectively. one signal appeared at $\delta_{\mathrm{H}} 7.21$ assignable to H-2', H-6' which representing $1^{\prime}, 3^{\prime}, 4^{\prime}, 5^{\prime}$ tetrasubstituted benzene ring. The presence of two symmetrical methoxy group was confirmed from the singlet signal at $\delta_{\mathrm{H}} 3.92 \mathrm{ppm}$ integrated for six protons. NMR data were in agreement with those reported about tricin ${ }^{19}$.

Compound 4: Luteolin: yellow powder, soluble in methanol, showed the same TLC pattern of a flavone. It gives $\mathrm{R}_{\mathrm{f}}$ value of 0.53 with dichloromethane/methanol (9.5:0.5 v/v). While ${ }^{1} \mathrm{H}-\mathrm{NMR}$ spectrum showed metacoupled doublets $(J=2.4 \mathrm{~Hz})$ at $\delta_{\mathrm{H}} 6.43$ and $6.20 \mathrm{ppm}(\mathrm{H}-$ 8 \& H-6; respectively) each of one proton, one singlet at $\delta_{\mathrm{H}} 6.53 \mathrm{ppm}(\mathrm{H}-3)$, one doublet at $\delta_{\mathrm{H}} 6.89 \mathrm{ppm}(J=9.2$, $\left.\mathrm{H}-5^{\prime}\right)$, doublet of doublet at $\delta_{\mathrm{H}} 7.38 \mathrm{ppm}\left(\mathrm{H}-6^{\prime}\right)$ overlapped with broad singlet at $\delta_{\mathrm{H}} 7.36 \mathrm{ppm}\left(\mathrm{H}-2^{\prime}\right)$. This data were in agreement with those reported about luteolin ${ }^{20}$.

Compound 5: Quercetin: yellow powder, soluble in methanol, attained a yellow color under long-wave UV light that intensifies after spray with $\mathrm{AlCl}_{3}$ using precoated silica gel TLC plates indicating their flavonol nature. It gives $\mathrm{R}_{\mathrm{f}}$ value of 0.51 with dichloromethane/ methanol $(9.5: 0.5 \mathrm{v} / \mathrm{v}) .{ }^{1} \mathrm{H}$ NMR spectrum showed metacoupled doublets $(\mathrm{J}=2 \mathrm{~Hz})$ at $\delta_{\mathrm{H}} 6.41$ and $6.19 \mathrm{ppm}$; $(\mathrm{H}-$ $8 \& \mathrm{H}-6$; respectively) each of one proton, two doublets at $\delta_{\mathrm{H}} 6.90 \mathrm{ppm}\left(J=8.4 \mathrm{~Hz}, \mathrm{H}-5^{\prime}\right)$ and $7.74 \mathrm{ppm}(J=2.4$ $\left.\mathrm{Hz}, \mathrm{H}-2^{\prime}\right)$ and doublet of doublet at $7.64 \mathrm{ppm}(J=2,8.4$ $\left.\mathrm{Hz}, \mathrm{H}-6^{\prime}\right)$. This data were in agreement with those cited in the literature for quercetin (Figure 1) ${ }^{20}$.

Compound 6: $\beta$-sitosterol- $\beta$-D-glucoside: white powder, soluble in dichloromethane and methanol mixture (1:1), attained violet color after spraying with $p$-anisaldehyde followed by heating at $110^{\circ} \mathrm{C}$ using precoated silica gel TLC plates. It gives $\mathrm{R}_{\mathrm{f}}$ value of 0.8 with dichloromethane/methanol $(8.5: 1.5 \mathrm{v} / \mathrm{v})$. DEPT-Q NMR displayed 29 carbons of $\beta$-sitosterol in addition to six signals were seen at $\delta_{\mathrm{C}} 102.9,72,75.7,78.8,78.4$ and $63.2 \mathrm{ppm}$ typical for glucose moiety. The ${ }^{1} \mathrm{H}$ NMR spectrum showed the anomeric proton of the glucose moiety at $\delta_{\mathrm{H}} 5.07(\mathrm{~d}, J=7.2 \mathrm{~Hz})$ indicating $\beta$-orientation. ${ }^{13} \mathrm{C}$ NMR (Pyridine- $\mathrm{d}_{5}, 100 \mathrm{MHz}$ ): $\delta_{\mathrm{C}} 37.8,30.6,78.4$, 39.7, 141.2, 122.2, 32.5, 32.4, 50.01, 37.2, 21.6, 40.3, 42.8, 57.1, 24.8, 28.9, 56.6, 12.3, 19.5, 36.7, 19.3, 34.5, 26.7, $46.4,29.8,20.3,19.7,23.7,12.5,102.9,75.7,78.9,72.0$, 78.8 and 63.2. NMR data were consistent with the literature ${ }^{21}$.

Compound 7: Entepicatechin-( $2 \alpha \rightarrow 7,4 \alpha \rightarrow 8)-$ ent-catechin: brown amorphous powder, soluble in methanol, no fluorescence under $\operatorname{UV}(\lambda$ 365), attained orange coloration after spraying with $p$-anisaldehyde followed by heating at $110^{\circ} \mathrm{C}$ using precoated silica gel TLC plates. It gives $R_{f}$ value of 0.52 with dichloromethane-methanol $(8: 2 \mathrm{v} / \mathrm{v}) .{ }^{1} \mathrm{H}$ NMR showed AB coupling system at $\delta_{\mathrm{H}} 4.12(\mathrm{~d}, J=5.2 \mathrm{~Hz} ; \mathrm{H}-3), 4.23(\mathrm{~d}, J=3.2 \mathrm{~Hz}$; $\mathrm{H}-4$ ), the meta-coupled doublets at 5.92, 6.05 (each d, $J=1.6 \mathrm{~Hz} ; \mathrm{H}-6, \mathrm{H}-8)$, a residual one aromatic proton singlet at $\delta_{\mathrm{H}} 6.08$ (s, H- $6^{\prime}$ ), and two AMX systems in the aromatic region $\left(\delta_{\mathrm{H}} 6.8-7.1\right)$ due to rings $\mathrm{B}$ and $\mathrm{E}$ confirmed the A-type procyanidin ${ }^{22}$. This class of compounds was also confirmed by the presence of 1 methylene, 13 methines and 16 quaternary carbons in the ${ }^{13} \mathrm{C}$ NMR spectrum, this doubly linked dimeric structure was also supported by the one acetal carbon at $\delta_{\mathrm{C}} 100.4$ in its DEPT-Q NMR spectrum. Also, the presence of signals at $\delta_{\mathrm{C}} 83.8$ and 68.3 attributable to $\mathrm{C}-2^{\prime}$ and $\mathrm{C}-3^{\prime}$ of ring $\mathrm{F}$, respectively, corresponded to a catechin terminal unit. Independent support for the presence of a 2,3-trans configurated 'lower' unit was available from the large coupling constant $\left(\mathrm{J}=8 \mathrm{~Hz}\right.$ ) of $\mathrm{H}-2^{\prime}$ and $\mathrm{H}^{-} 3^{\prime}$ (ring F). NMR data were consistent with the literature ${ }^{23-24}, \mathrm{com}-$ pound 7 was identified as entepicatechin- $(2 \alpha \rightarrow 7,4 \alpha \rightarrow 8)$ ent-catechin (Figure 1).

Compound 8: Rutin: yellow powder, soluble in methanol, attained a purple color which turned yellow after spraying with $p$-anisaldehyde followed by heating at $110^{\circ} \mathrm{C}$ using precoated silica gel TLC plates. It gives $\mathrm{R}_{\mathrm{f}}$ value of 0.43 with ethyl acetate/formic acid/acetic acid/water (100:11:11:27 v/v). ${ }^{1} \mathrm{H}$ NMR spectrum showed the signals characteristic for compound $\mathbf{5}$ (quercetin); ring $B$ is substituted in $3^{\prime}$ and $4^{\prime}$ positions and this was confirmed by the presence of ABX spin system; H$5^{\prime}(6.89, \mathrm{~d}, J=8 \mathrm{~Hz}), \mathrm{H}-6^{\prime}(7.66, \mathrm{dd}, J=2,8 \mathrm{~Hz}), \mathrm{H}-2^{\prime}(7.68$, overlapped). Ring A is substituted only in 5 and 7 positions which was verified by the presence of two 
broad singlets of $\mathrm{H}-6$ at $\delta_{\mathrm{H}} 6.22 \mathrm{ppm}$ and $\mathrm{H}-8$ at $\delta_{\mathrm{H}} 6.4$ $\mathrm{ppm}$; in additional to the signals of the sugar moieties including a doublet appeared at $\delta_{\mathrm{H}} 5.12 \mathrm{ppm}(\mathrm{d}, J=6.8$ $\mathrm{Hz}$ ) indicated an anomeric proton of a $\beta$-D-glucose moiety, while those at $\delta_{\mathrm{H}} 4.54$ (broad singlet) with that at $\delta_{\mathrm{H}} 1.13(3 \mathrm{H}, \mathrm{d}, J=5.6 \mathrm{~Hz})$ revealed the presence of an $\alpha$-rhamnose. ${ }^{13} \mathrm{C}$ NMR $\left(\mathrm{CD}_{3} \mathrm{OD}, 100 \mathrm{MHz}\right): \delta_{\mathrm{C}} 159.3$, 135.6, 179.4, 163, 100, 166, 94.9, 158.6, 105.6, 123.1, 117.7, 145.9, 149.8, 116.1, 123.5, 104.7, 75.7, 78.2, 77.2, 71.4, 68.6, 102.4, 72.1, 72.2, 73.9, 69.6, 17.8. Data were consistent with previously published data ${ }^{25}$.

Compound 9: Orientin: yellow powder, soluble in methanol, attained a purple color under long-wave UV light; turned yellow after spray with $\mathrm{AlCl}_{3}$ and turned yellow after spraying with $p$-anisaldehyde followed by heating at $110^{\circ} \mathrm{C}$ using precoated silica gel TLC plates. It gives $R_{f}$ value of 0.35 with dichloromethane-methanol $(8: 2 \mathrm{v} / \mathrm{v}) .{ }^{13} \mathrm{C}-\mathrm{NMR}$ spectrum revealed the signals of flavone glycosides; 21 carbons, including one carbonyl at $\delta_{\mathrm{C}} 182.02 .{ }^{1} \mathrm{H}-\mathrm{NMR}$ revealed the signals of three aromatic protons of $\mathrm{ABX}$ aromatic system in ring $\mathrm{B}$ at $\delta_{\mathrm{H}} 6.86\left(1 \mathrm{H}, \mathrm{d}, J=8.4 \mathrm{~Hz}, \mathrm{H}-5^{\prime}\right), 7.47\left(1 \mathrm{H}, \mathrm{br} \mathrm{s}, \mathrm{H}-2^{\prime}\right)$, and 7.53 (overlapped dd, $J=8.4 \mathrm{~Hz}, \mathrm{H}-6^{\prime}$ ) indicating that the aglycone is luteolin. ${ }^{13} \mathrm{C}$-NMR chemical shifts of sugar moiety $\left(\delta_{\mathrm{C}} 73.3,70.9,78.7,70.6,82\right.$ and 61.6$)$ were typical of $C$-glucopyranosyl moiety. Presence of only one protonated carbon signal at $\delta_{\mathrm{C}} 98.1$ confirmed that sugar moiety was attached to C-8. ${ }^{13} \mathrm{C}$ NMR (DMSO, 100 MHz): $\delta_{\mathrm{C}} 164,102.3,182,160.3,98.1,162.6,104.5,156$, $104,121.9,114,145.8,149.6,115.6$ and 119.3, 73.3, 70.9, 78.7, 70.6, 82 and 61.6. NMR data were consistent with that reported for orientin ${ }^{26}$.

The results (Figure 2) revealed that Dictyosperma album (56.63 and $8.60 \mathrm{mg} \mathrm{GAE} / \mathrm{g}$, respectively) gives significantly higher phenolics and flavonoids content than Archintophoenix alexandrae leaves (13.72 and $3.97 \mathrm{mg} \mathrm{RE} / \mathrm{g}$, respectively). From Figure 3; it could be concluded that Dictyosperma album leaves shows significantly higher antioxidant activity than Archintophoenix alexandrae leaves with the values of 243.51 and $129.40 \mu \mathrm{g} \mathrm{AECE} / \mathrm{g}\left(\mathrm{IC}_{50}=60\right.$ and $108.5 \mu \mathrm{g} / \mathrm{ml}$, respectively). Reducing power was highlighting in Dictyosperma album $\left(\mathrm{A}_{700} \mathrm{~nm}=1.217 \pm 0.082\right)$ than that found for Archintophoenix alexandrae $\left(\mathrm{A}_{700} \mathrm{~nm}=0.219 \pm\right.$ 0.008). Ascorbic acid $\left(\mathrm{A}_{700} \mathrm{~nm}=0.803 \pm 0.0907\right)$ was used as reference as it is reported as a good antioxidant drug.

This study validated the direct correlations between total phenolic concentrations and antioxidant activities (anti-radical capacity and reducing power). Hence, we could conclude that these phenolics and flavonoids are responsible for the observed antioxidant activity in this study. So, it was important to isolate the individual phytochemical constituents. The number of phenolic compounds isolated from Dictyosperma album (tricin, rutin and orientin) is less than that isolated from
Archintophoenix alexandrae (tricin, luteolin, quercetin, entepicatechin-( $2 \alpha \rightarrow 7,4 \alpha \rightarrow 8)$-ent-catechin and rutin). But the antioxidant activity of Dictyosperma album leaves is higher than that of Archontophoenix alexandrae leaves. This may be due to the higher antioxidant activity of orientin when compared with luteolin as reported $\mathrm{in}^{27}$ or presence of higher content of tricin or presence of other highly antioxidative secondary metabolites which could not be isolated due to its small amount.

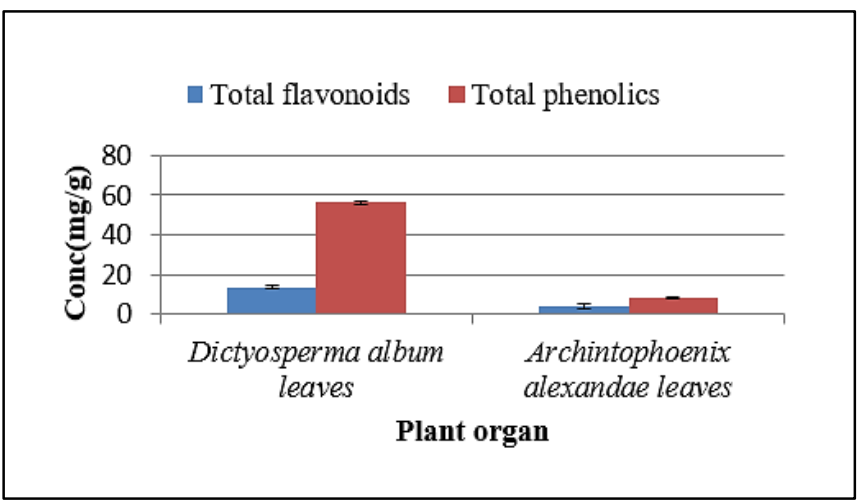

Figure 2. Total phenolics, total flavonoids content of Archontophoenix alexandrae and Dictyosperma album leaves.

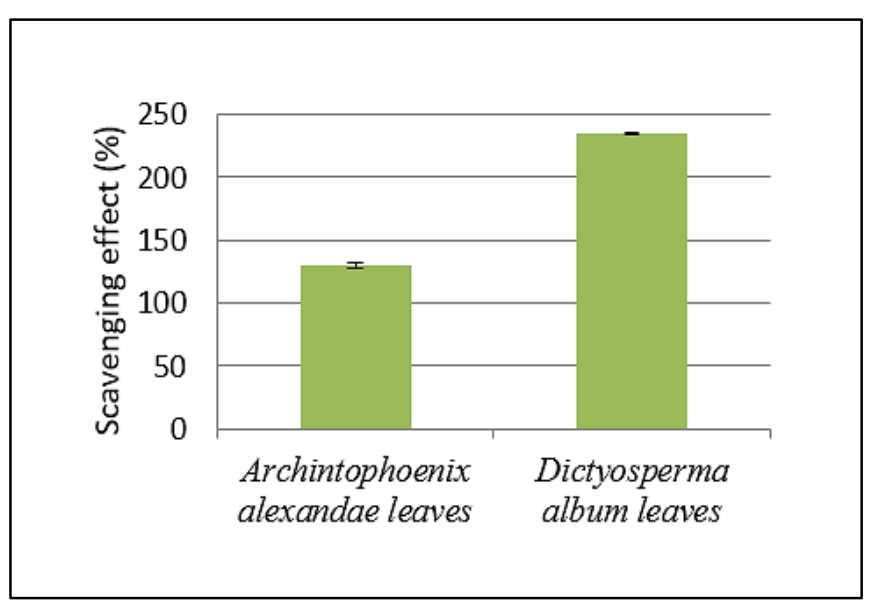

Figure 3. DPPH free radical scavenging activity of the $80 \%$ methanolic extracts of Archontophoenix alexandrae and Dictyosperma album.

\section{CONCLUSION}

The result of this study revealed that Dictyosperma album contains higher amount of phenolic compounds mainly flavonoids than Archontophoenix alexandrae. Nine compounds were isolated and identified for the first time from Archontophoenix alexandrae and Dictyosperma album leaves. The antioxidant activity of Dictyosperma album leaves is higher than that of Archontophoenix alexandrae leaves. Hence, further biological investigation is needed for both tested extracts and may be useful for their nutritional and medicinal functions. 


\section{ACKNOWLEDGEMENT Nil}

\section{Conflict of interest}

The authors have no conflict of interest.

\section{Funding}

None to declare.

\section{Ethics approval}

None to declare.

\section{Article info:}

Received March 15, 2021

Received in revised form August 17, 2021

Accepted August 26, 2021

\section{REFERENCES}

1. Aboul-Enein AM, El-Ela FA, Shalaby EA, El-Shemy HA. Traditional medicinal plants research in Egypt: Studies of antioxidant and anticancer activities. J Med Plants Res. 2012;6(5):689-703.

2. Vayalil PK. Antioxidant and antimutagenic properties of aqueous extract of date fruit (Phoenix dactylifera L. Arecaceae). J Agric Food Chem. 2002;50(3):610-7.

3. Sengab AEB, El Dina M, Elgindi MR, Elsaid MB. Biological studies of isolated triterpenoids and phenolic compounds identified from Wodyetia bifurcata family Arecaceae. J Pharmacogn Phytochem. 2015;3(6):67-73.

4. Hoffmann J, Lopes Crizel R, de Ávila Madruga N, Barbieri R, Rombaldi C, Chaves F. Flavan-3-ol, flavanone, flavone, flavonol, phenolic acid, and stilbene contents of four Butia species (Arecaceae). Fruits. 2018;73(2):125-37.

5. Koolen HH, Soares ER, da Silva FM, de Oliveira AA, de Souza AQ, de Medeiros LS, et al. Mauritic acid: a new dammarane triterpene from the roots of Mauritia flexuosa Lf (Arecaceae). Nat Prod Res. 2013;27(22):2118-25.

6. Koolen HH, Soares ER, da Silva FM, de Oliveira AA, de Souza AQ, de Medeiros LS, et al. Mauritic acid: a new dammarane triterpene from the roots of Mauritia flexuosa Lf (Arecaceae). Nat Prod Res. 2013;27(22):2118-25.

7. Koolen HH, Soares ER, Silva F, de Souza AQ, Rodrigues Filho E, de Souza AD. Triterpenes and flavonoids from the roots of Mauritia flexuosa. Rev Bras Farmacogn. 2012;22(1):189-92.

8. Uhl NW, Dransfield, J. Genera Palmarum: A classification of palms based on the Work of Harold E. Moore, Jr. Lawrence, Kan: Allen Press; 1987.

9. Wiersema JH, León B. World economic plants: a standard reference. $1^{\text {st }}$ ed. Boca Raton: CRC press; 1999.

10. Grubben GJ, Denton OA. Plant Resources of Tropical Africa (PROTA). Wageningen, Netherlands: Prota Foundation; 2004.
11. Grubben GJ, Denton OA. Plant Resources of Tropical Africa (PROTA). Wageningen, Netherlands: Prota Foundation; 2008.

12. Allaby M. A dictionary of plant sciences. $3^{\text {rd }}$ ed. New York: Oxford University Press; 2012.

13. Williams CA, Harborne JB, Clifford HT. Negatively charged flavones and tricin as chemosystematic markers in the Palmae. Phytochemistry. 1973;12(10):2417-30.

14. Waksmundzka-Hajnos M, Sherma J, Kowalska T. Thin layer chromatography in phytochemistry. $1^{\text {st }}$ Ed. Boca Raton: CRC Press; 2008.

15. Ismail M, Owisa AI, Hettab M, Mohammeda R. Total phenolics and flavonoids content, antioxidant activity and GC/MS analyses of Euphorbia grandialata. JAPS. 2017;7(06):176-81.

16. El-Kashoury E-S, Hetta M, Yassin N, Hassan H, El-Awdan S, Afifi N. Comparative DNA profiling, phytochemical investigation, and biological evaluation of two Ficus species growing in Egypt. Pharmacognosy Res. 2013;5(4):291-9.

17. Cobaleda-Velasco M, Alanis-Bañuelos RE, Almaraz-Abarca N, Rojas-López M, González-Valdez LS, Ávila-Reyes JA, et al. Phenolic profiles and antioxidant properties of Physalis angulata L. as quality indicators. J Pharm Pharmacogn Res. 2017;5(2): 114-28.

18. Cayme J-MC, Ragasa CY. Structure elucidation of $\beta$-stigmasterol and $\beta$-sitosterol from Sesbania grandifora [Linn.] Pers. and $\beta$-carotene from Heliotropium indicum Linn. by NMR spectroscopy. KIMIKA. 2004;20(1):5-12.

19. Chung I-M, Hahn S-J, Ahmad A. Confirmation of potential herbicidal agents in hulls of rice, Oryza sativa. J Chem Ecol. 2005;31(6):1339-52.

20. Markham KR, Chari VM. Carbon-13 NMR spectroscopy of flavonoids. In: The Flavonoids: Advances in Research. Boston: Springer; 1982. p. 19-134.

21. Bayoumi SA, Rowan MG, Beeching JR, Blagbrough IS. Constituents and secondary metabolite natural products in fresh and deteriorated Cassava roots. Phytochemistry. 2010;71(5-6):598-604.

22. Jacques D, Haslam E, Bedford GR, Greatbanks D. Plant proanthocyanidins. Part II. Proanthocyanidin-A2 and its derivatives. J Chem Soc, Perkin Transactions 1. 1974:2663-71.

23. Balde A, Pieters L, Gergely A, Kolodziej H, Claeys M, Vlietinck A. A-type proanthocyanidins from stem-bark of Pavetta owariensis. Phytochemistry. 1991;30(1):337-42.

24. Lou H, Yamazaki Y, Sasaki T, Uchida M, Tanaka H, Oka S. Atype proanthocyanidins from peanut skins. Phytochemistry. 1999; 51(2):297-308.

25. Moawad A, Amin E, Mohammad R. Diffusion-ordered Spectroscopy of Flavonol Mixture from Mesembryanthemum forsskaolii (Aizoaceae). Eur J Med Chem. 2016;16:1-8.

26. Burns DC, Ellis DA, March RE. A predictive tool for assessing 13C NMR chemical shifts of flavonoids. Magn Reson Chem. 2007:45(10):835-45.

27. Choi JS, Islam MN, Ali MY, Kim YM, Park HJ, Sohn HS, et al. The effects of C-glycosylation of luteolin on its antioxidant, antiAlzheimer's disease, anti-diabetic, and anti-inflammatory activities. Arch Pharm Res. 2014;37(10):1354-63. 